Бұл CC BY-NC-ND лицензиясы бойынша қол жетімді мақала (https://creativecommons.org/licenses/by-nc-nd/3.0/) «Ғылымның өзекті мәселелері» - Халықаралық практикалық интернет- конференция материалдары

Басылым II, Қараша 2019

ISBN 978-601-323-144-0

https://doi.org/10.31643/2019.011

\author{
Шорманов Серікхан Тұрсынханұлы \\ «Қазақстан Республикасы Еңбек және \\ халықты әлеуметтік қорғау министрлігінің \\ Еңбекті қорғау жөніндегі республикалық \\ ғылыми-зерттеу институты» ШЖҚ РМК \\ аға ғылыми қызметкері \\ Нұр-Сұлтан қ., Қазақстан \\ E-mail: nauka@rniiot.kz ORCID ID: 0000-0003-0170-3990
}

\title{
Қазақстан Республикасындағы еңбек қауіпсіздігі мен еңбекті қорғау жүйесінің жай-күйі
}

\begin{abstract}
Абстракт: Мемлекеттік реттеу шараларын тиімді біріктіру, өндірістегі практикалық іске асыру мүмкіндіктері және қауіпсіз еңбекті қамтамасыз етудегі ғылыми инновациялар негізінде еңбекті қорғауды басқару жүйесін құру негізгі бағыттары болып табылады. Өндірістік жарақаттанудың жай-күйі және оларды төмендету жолдары Қазақстан Республикасында кәсіби тәуекелдерді басқару негізінде халықаралық, ұлттық стандарттарды және интеграцияланған еңбекті қорғауды басқару жүйесін енгізу болып табылады. Қазақстандағы еңбек қауіпсіздігі және еңбекті қорғаудың ұлттық жүйесі әлеуметтік әріптестердің еңбек қауіпсіздігі және еңбекті қорғау мәселелері бойынша мемлекеттік реттеу және ынтымақтастық тетіктерін қамтиды. Сонымен қатар жұмыскерлердің еңбек қауіпсіздігі жағдайларын тұрақты жақсартуға жұмыс берушілердің экономикалық және қаржылық мүдделілігін арттыру, өндірістегі жазатайым оқиғалардан сақтандыру жүйесі еңбек қауіпсіздігі шарттары бойынша өндірістік объектілердің тәуекелдерін бағалау нәтижелерімен өзара байланысты.
\end{abstract}

Түйінді сөздер: еңбек қауіпсіздігі және еңбекті қорғау жүйесі, өндірістік жарақаттану динамикасы, халықаралық және ұлттық стандарттарды енгізу, OHSAS 18001 өнеркәсіптік қауіпсіздік пен еңбекті қоғауды басқару жүйесінің халықаралық стандарттары, еңбекті қорғау мен еңбек қауіпсіздігінің ұлттық жүйесі.

Қазақстанда еңбек қауіпсіздігі және еңбекті қорғау жүйесі ондаған жылдар бойы қалыптасты. 2015 жылғы 23 қарашадан бастап Қазақстан Республикасының Еңбек кодексі қабылданды. «Еңбек қауіпсіздігі мен еңбекті қорғау» бөлімін әзірлеу кезінде еңбек қауіпсіздігі мен еңбекті қорғау саласындағы халықаралық стандарттардың нормалары мен талаптары ескерілді [1].

Қазақстанда жүргізіліп жатқан әлеуметтік-экономикалық өзгерістер еңбек қауіпсіздігі мен еңбекті қорғаудың көптеген мәселелерін, еңбек қауіпсіздігі жағдайларының нашарлауын, өндірістік жарақаттану мен кәсіби аурулардың жоғары көрсеткіштерін айқындады.

Өндірістік жарақаттану динамикасы соңғы үш жылда өндірісте жыл сайын 1,6 мыңнан астам жазатайым оқиғаға жол берілетінін көрсетеді, өліммен аяқталған зардап шеккендердің саны жоғары деңгейде сақталуда. 2016 жылы өндірісте 248 адам, 2017 жылы 244 адам, 2018 жылы - 220 адам, 2019 жылдың 9 айында - 111 адам қайтыс болды [3].

Әр түрлі салаларда жарақаттану себептерінің өз ерекшеліктері бар, бірақ барлығы үшін жалпы мыналар болып табылады: жұмыстарды жүргізуді қанағаттанарлықсыз ұйымдастыру, еңбек және өндірістік тәртіпті бұзу, жұмыстың қауіпсіз тәсілдеріне жеткіліксіз оқыту, қауіпсіздік техникасы талаптарының бұзылуы. 
Жоғарыда айтылғанды ескере отырып, өндірістік жарақаттануды азайту мақсаты халықаралық және ұлттық стандарттарды енгізу болып табылады, олар өндірістік объектілерді еңбек жағдайлары бойынша аттестаттауды қамтиды. Еңбек жағдайлары бойынша аттестаттау жұмыс берушіге зиянды еңбек жағдайлармен нақты жұмыс орындарын, жұмыс орындарының жарақат қауіпсіздігін қамтамасыз ету және жұмыскерлерді арнайы киіммен, арнайы аяқ киіммен және басқа да жеке қорғану құралдарымен қамтамасыз етудегі кемшіліктерді объективті анықтауға мүмкіндік береді, бұл өз кезегінде мақсатты бағытталған ұйымдастырушылық және гигиеналық ұсынымдардың негізінде еңбек үдерісінің қауіптілігі, тәуекелдер, өндірістік жарақаттану деңгейін қысқартуға, жалпы және кәсіби аурулар төмендетуге мүмкіндік береді. Еңбек қауіпсіздігі және еңбекті қорғау саласындағы ісшараларды орындау кезектілігін айқындайды, негізсіз материалдық және қаржылық шығындарды алып тастайды.

Республика кәсіпорындарында OHSAS 18001 еңбекті қорғау мен өнеркәсіптік қауіпсіздікті басқару жүйесінің халықаралық стандарттарын жұмыс берушілер 2005 жылдан бастап енгізе бастады.

Қазақстан Республикасы Сауда және интеграция министрлігі Техникалық реттеу және метрология комитетінің веб-сайтында орналастырылған облыстар, Нұр-Сұлтан, Алматы және Шымкент қалалары әкімдіктерінің деректері бойынша, 2018 жылғы 1 қаңтардағы жағдай бойынша, Қазақстанның 1410 кәсіпорны OHSAS 18001 стандартына сәйкестігіне менеджмент жүйесін енгізді және сертификаттады. Жергілікті атқарушы органдардың еңбек инспекциясы органдарының мәліметтері бойынша республикада барлығы 2 мыңнан астам кәсіпорын еңбек қауіпсіздігі және еңбекті қорғау жөніндегі халықаралық және ұлттық стандарттарды енгізді.

Нәтижесінде, егер 2009 жылы өндірістегі жазатайым оқиғалардан 355 адам қайтыс болса, 2018 жылдың қорытындысы бойынша - 220 адам қайтыс болды, өліммен аяқталған өндірістік жарақаттану деңгейі 38 пайызға төмендеді [3].

2014 жылғы қазанда «Еңбек қауіпсіздігі мен гигиенасына жәрдемдесетін негіздер туралы конвенцияны (187-конвенция) ратификациялау туралы» Қазақстан Республикасының Заңы қабылданды [2].

Осы Конвенцияның негізгі бағыты жұмыс берушілер мен жұмыскерлердің неғұрлым өкілді ұйымдарымен консультациялар негізінде ұлттық саясат, ұлттық жүйе және ұлттық бағдарламаны әзірлеу арқылы өндірістік жарақаттану, кәсіптік аурулар және өндірісте адамдардың қаза болуы жағдайларының алдын алу болып табылады.

Қазақстан Республикасының осы Конвенцияға қатысуы еңбек қауіпсіздігі мен гигиенасы саласындағы халықаралық ынтымақтастық үшін маңызды мәнге ие және Қазақстанның осы саладағы халықаралық нормаларды сақтау мен орындауға бейілділігін растайды.

Қазақстандағы еңбек қауіпсіздігі және еңбекті қорғаудың ұлттық жүйесі әлеуметтік әріптестердің еңбек қауіпсіздігі және еңбекті қорғау мәселелері бойынша мемлекеттік реттеу және ынтымақтастық тетіктерін (республика кәсіпорындарында мемлекеттік және ішкі бақылау және еңбекті қорвауды басқару жүйесі) қамтиды.

Жұмыс берушілерге еңбек қауіпсіздігі және еңбекті қорғау жөніндегі талаптарды қатаң сақтауды ұйғаратын міндетті және ерікті ынталандыру жүйесі құрылды (Әкімшілік құқық бұзушылық туралы кодекске және Қылмыстық кодексе сәйкес еңбек қауіпсіздігі және еңъекті қ̧орвау жөніндегі нормаларды бұзzаны үшін жұмыс берушілердің жауапкершілігін күшейту).

Әкімшілік кедергілерді алып тастау және жұмыс берушілердің, бірінші кезекте, шағын және орта бизнес өкілдерінің шығындарын азайтуды көздейтін жұмыс берушілердің еңбек қауіпсіздігі жағдайларының заңнама талаптарына сәйкестігін ерікті декларациялау жүйесі енгізілді. Еңбек қауіпсіздігі және еңбекті қорғау жөніндегі салалық нормалар жүйесі, санитарлық ережелер мен гигиеналық нормативтер, өндірістегі жазатайым оқиғалар мен 
кәсіптік ауруларды есепке алу және статистикалық есептіліктің мемлекеттік және ведомстволық жүйесі қалыптастырылды.

Сонымен қатар жұмыскерлердің еңбек қауіпсіздігі жағдайларын тұрақты жақсартуға жұмыс берушілердің экономикалық және қаржылық мүдделілігін арттыру, өндірістегі жазатайым оқиғалардан сақтандыру жүйесі еңбек қауіпсіздігі шарттары бойынша өндірістік объектілердің тәуекелдерін бағалау нәтижелерімен өзара байланысты.

Қазақстандағы еңбек қауіпсіздігі мен еңбекті қорғаудың қанағаттанғысыз жай-күйінің себебі қазіргі уақытта қолданыстағы еңбекті қорғауды басқару жүйесі олардың алдын алуға емес, өндірістегі жазатайым оқиғаларға ден қою қағидаттарына құрылғаны болып табылады. Кәсіпорындардағы жұмыскерлердің денсаулығына қолайсыз өндірістік факторлардың әсерін талдау іс жүзінде жүргізілмейді. Олардың пайда болу себептері емес, жазатайым оқиғалардың салдары ғана тіркеледі. Бұл ретте, негізгі назар өндірісте жұмыскерлер денсаулығының зақымдану жағдайларының алдын алуға емес, ал жазатайым оқиғалар орын алған кезде өтемақылық іс-шараларға бөлінеді.

Жалпы алғанда, еңбек қауіпсіздігі мен еңбекті қорғаудың қанағаттанғысыз жайкүйінің негізгі себептерінің арасында мыналарды атап өтуге болады:

- республика ұйымдарында еңбекті қорғауды басқару жүйесінің жұмыс істеуін қамтамасыз етпеу;

- кәсіпорындардың көптеген нормативтік-құқықтық актілері мен нормативтіктехникалық құжаттарының уақыт талаптарына, технологиялық үрдіс деңгейіне сәйкес келмеуі, кәсіпорындардың еңбекті қорғау жөніндегі нормативтік-құқықтық актілермен жеткіліксіз қамтамасыз етілуі;

- мемлекеттік еңбек инспекциясының бақылау қызметіндегі кемшіліктер, Қазақстан Республикасы Еңбек заңнамасының сақталуына тәуекел дәрежесін бағалау жүйесінің жетілдірілмеуі;

- жұмыскерлердің денсаулығын және еңбекті қорғау мәселелерін мемлекеттік реттеудің ғылыми негізін қамтамасыз етуге арналған зерттеу инфрақұрылымының жеткіліксіз дамуы;

- кәсіптік аурулардың ерте белгілерін анықтаудың төмен деңгейі және алдын алу жұмыстарының нашар жүргізілуі;

- жұмыскерлердің өндірістегі жазатайым оқиғалардан міндетті сақтандыру жүйесімен нашар қамтылуы және әлеуметтік қорғаудың басқа деңгейлерінен төленетін төлемдермен өзара байланыстың болмауы;

- заңнамада көзделген әлеуметтік әріптестік тетіктері толық көлемде іске асырылмайды;

- кәсіпорындарда еңбек қауіпсіздігі және еңбекті қорғау жөніндегі ұйымдастыру ісшараларына жұмыскерлерді жеткіліксіз тарту;

- жекелеген жұмыс берушілердің, әсіресе шағын және орта кәсіпорындар басшыларының еңбекті қорғау жағдайына жауапсыз қарауы, еңбек және технологиялық тәртіптің төмен деңгейі, басшы жұмыскерлердің өндірістік қауіпсіздік және еңбекті қорғау саласында тиісті дағдылары мен біліктілігінің болмауы.

Осыған байланысты, келтірілген кемшіліктерді жою республиканың кәсіпорындарында еңбек қауіпсіздігін және еңбекті қорғаудыңжай-күйін жақсартуға ықпал етеді. Қазақстан Республикасында еңбекті қорғауды басқарудың қолданыстағы жүйесі өндірістік жарақаттану көрсеткіштерін дамыған елдер деңгейіне дейін төмендетуді қамтамасыз ету үшін халықаралық стандарттарға сәйкес келтіріледі.

«Қазақстан Республикасы Еңбек және халықты әлеуметтік қорғау министрлігінің Еңбекті қорғау жөніндегі республикалық ғылыми-зерттеу институты» ШЖҚ РМК өткен жылы «Қазақстан Республикасы экономикасының басым секторларында қауіпсіз еңбекті қамтамасыз етудің ғылыми-әдістемелік негіздерін әзірлеу» тақырыбына ғылыми-зерттеу жұмысын жүргізді. Ағымдағы жылы ғылыми-зерттеу жұмысының нәтижелері кәсіби 
тәуекелдерді басқару негізінде еңбекті қорғауды басқарудың әзірленген біріктірілген жүйесі түрінде 20 пилоттық кәсіпорынға енгізілуде.

Осылайша, негізгі бағыттар мемлекеттік реттеу шараларын тиімді біріктіру, өндірістегі практикалық іске асыру мүмкіндіктері және қауіпсіз еңбекті қамтамасыз етудегі ғылыми инновациялар негізінде еңбекті қорғауды басқару жүйесін құру болып табылады.

\author{
Shormanov Serikhan Tursynkhanovich \\ Senior Research, RNE «Republican Research Institute for Labor \\ Protection of the Ministry of Labor and \\ Social Protection of the Population \\ of the Republic of Kazakhstan» Nur-Sultan, Kazakhstan. \\ E-mail: nauka@rniiot.kz ORCID ID: 0000-0003-0170-3990
}

\title{
State of system of safety and labour protection in Republic of Kazakhstan
}

\begin{abstract}
The main areas are the effective integration of state regulation measures, the possibility of practical implementation at the workplace and the creation of a labor protection management system based on scientific innovations in the field of safe labor protection. The state of industrial injuries and ways to reduce it is the introduction of international, national standards and integrated labor protection management systems based on professional risk management in the Republic of Kazakhstan. The national system of labor and health protection in Kazakhstan includes mechanisms of state regulation and cooperation on labor protection and the protection of social partners. At the same time, increasing the economic and financial interest of the employer in constantly improving the safety of workers, the accident insurance system is interconnected with the results of risk assessment of industrial facilities under labor protection conditions.

Keywords: system of safety and labour, loud speaker of productive traumatism protection, introduction of international and national standards, international standards of control system by a labour and industrial safety of OHSAS 18001 protection, national system of safety and labour protection.
\end{abstract}

Мақалаға сілтеме: Шорманов, С (2019) Қазақстан Республикасындағы еңбек қауіпсіздігі мен еңбекті қорғау жүйесінің жай-күйі. «Ғылымның өзекті мәселелері» Халықаралық практикалық интернет- конференция материалдары / Materials of International Practical Internet Conference "Challenges of Science". ISBN 978-601-323144-0. Басылым II, 2019. Бет: 64-67. https://doi.org/10.31643/2019.011

\section{Пайдаланылған әдебиеттер тізімі}

[1] 2015 жылғы 23 қарашадағы № 414-V Қазақстан Республикасының Еңбек кодексі (13.06.2017 ж. берілген өзгерістер мен толықтырулармен). http://adilet.zan.kz/kaz/docs/K1500000414

[2] «Еңбек қауіпсіздігі мен гигиенасына жәрдемдесетін негіздер туралы конвенцияны (187-конвенция) ратификациялау туралы» 2014 жылғы 20 қазандағы № 243-V ҚР3 Қазақстан Республикасының Заңы. http://adilet.zan.kz/kaz/docs/Z1400000243

[3] Республика ұйымдарындағы өндірістік жарақаттанудың жай-күйі туралы мемлекеттік еңбек инспекторларының жиынтық есептері. http://adilet.zan.kz/kaz/docs/K070000251_ 